\title{
Report of a three-year monitoring programme at Heshang Cave, Central China
}

\author{
Chaoyong $\mathrm{Hu}^{1}$, Gideon M. Henderson ${ }^{2}$, Junhua Huang ${ }^{1}$, Zhenghong Chen $^{3}$,
}

Kathleen R. Johnson ${ }^{2}$

\begin{abstract}
:
Hu C., Henderson G.M., Huang J., Chen Z. and Johnson K.R. 2008. Report of a three-year monitoring programme at Heshang Cave, Central China. International Journal of Speleology, 37(3), 143-151. Bologna (Italy). ISSN 0392-6672.

Heshang Cave is situated in central China $\left(30^{\circ} 27^{\prime} \mathrm{N}, 110^{\circ} 25^{\prime} \mathrm{E} ; 294 \mathrm{~m}\right)$ in the middle reaches of the Yangtze Valley, a region strongly impacted by the East Asian Monsoon. It contains large annually-laminated Holocene and late Pleistocene stalagmites which capture past monsoon behaviour with seasonal resolution, and could enhance understanding of the amplitude and frequency of monsoon behaviour in different climate states. In this paper, we present results of a 3-year monitoring programme at Heshang. T loggers outside the cave agree closely with $\mathrm{T}$ data from nearby meteorological stations. T at the site of growth of the largest recovered stalagmite averages $18^{\circ} \mathrm{C}$ (identical to mean annual T outside the cave) with a seasonal amplitude of $5^{\circ} \mathrm{C}$ (about one fifth of the external cycle). Rainfall measurements from a station $3 \mathrm{~km}$ from the cave indicate strong summer monsoon rain in 2004 and 2005, but rather weaker summer rain (by $\approx 30 \%$ ) in 2006 . Drip rate at the monitoring site has a base flow of 14 drips/minute and shows a sharp increase to $\approx 40$ drips/minute early in the summer rains of 2004 and 2005 , followed by a gradual return to base-flow as the monsoon weakens. This abrupt change presumably represents threshold behaviour in the hydrological system. This threshold is not passed in 2006 and there is no abrupt increase in drip rate, indicating the sensitivity of this site (and presumably of speleothem chemistry in this cave) to monsoon rainfall. Results are also reported from a 10-month deployment of a Stalagmate drip counter, and for $\mathrm{CO}_{2}$ levels in Heshang Cave. Overall, this monitoring work represents an essential dataset for interpretation of the chemistry of drip waters, of carbonates grown on glass slides and, ultimately, of long speleothem records of past climate from Heshang Cave.
\end{abstract}

Keywords: Stalagmite; speleothem; cave monitoring; palaeoclimate; cave geochemistry

received 20 August 2007; Revised 23 October 2007; Accepted 14 February 2008

\section{INTRODUCTION}

Heshang Cave is situated in Central China, a region whose climate is dominated by the East Asian monsoon. This large climate cycle moves significant heat and moisture within the global climate system (Webster et al., 1998). It influences, and is influenced by, climate in other regions such as the tropics via the El Niño Southern Oscillation (Krishna Kumar et al., 1999) and the North Atlantic via changes in ocean circulation (Wang et al., 2001). Understanding of past changes of the East Asian monsoon, and the mechanisms driving such change, are therefore important to a full understanding of global climate dynamics. In addition, the East Asian monsoon is of great societal significance for the densely populated region that it

1 Key Laboratory of Biogeology and Environmental Geology of Ministry of Education (China University of Geosciences), Wuhan 430074, China

2 Department of Earth Sciences, Oxford University, Parks

Road, Oxford, OX1 3PR, UK

3 Wuhan Regional Climate Center, Wuhan 430074, China influences. High rainfall during strong monsoon years can lead to severe flooding, so prediction of the onset and strength of the monsoon is an important goal to aid in planning for agriculture and water resources. These scientific and societal goals amply justify the study of speleothem records from Central China and have motivated extensive work on a variety of Chinese caves in recent years (e.g. Wang et al., 2001 Wang et al., 2005; Hu et al., 2008).

Heshang (meaning "monk" in Mandarin Chinese) was first visited for scientific purposes in the late 1990s, and speleothem samples first recovered in 1998. Early work on these samples demonstrated the potential of the cave for reconstruction of the past East Asian monsoon at very high resolution for at least the last 20 kyr. Publications on the cave have, to date, established the chronology of two speleothems (Hu et al., 2005; 2008), investigated the use of dissolved $\mathrm{Si}$ as a paleo-proxy in speleothems (Hu et al., 2005), established a quantitative Holocene record of rainfall in Central China (Hu et al., 2008), and investigated the reconstruction of past climate at seasonal resolution using Heshang speleothems (Johnson et al., 2006). 
This work, particularly that involved in seasonal reconstruction, led to the conclusion that a full understanding of the Heshang Cave environment was required if chemical data was to be reliably converted into climate variables such as rainfall and temperature. This conclusion concurs with that reached from seasonal-resolution speleothem studies in other regions (Fairchild et al., 2001; Treble et al., 2003) indicating that understanding of cave hydrology and chemistry is a pre-requisite for the use of speleothems for high-resolution climate reconstruction. Published studies have strived for such understanding by monitoring the cave environment, including that in Crag Cave, Ireland (3 years, Baldini et al., 2006); Kooringa Cave, Australia (2.5 years, McDonald et al., 2004); and Pere Noel Cave, Belgium (6 years, Genty $\&$ Deflandre, 1998). The Genty and Deflandre study also lists earlier and unpublished studies of drip-rate variability. Such previous studies of cave hydrology clearly demonstrate differences in hydrological flowregime and indicate that the environment for each cave must be understood independently to achieve reliable climate records. To develop such understanding at Heshang Cave we initiated a thorough monitoring programme in late 2003. Here we report the results of the first three years of that monitoring programme. We present a full description of the cave, together with records of temperature, rainfall, drip rate, and $\mathrm{CO}_{2}$.

\section{REGIONAL SETTING}

Heshang Cave is situated in the Qingjiang Valley of the middle reaches of the Yangtze River at $30^{\circ} 27^{\prime} \mathrm{N}$, $110^{\circ} 25^{\prime} \mathrm{E}$; and $294 \mathrm{~m}$ altitude (Fig 1). The region is mountainous and, although reasonably densely populated, the nearest large city (Yichang) is $100 \mathrm{~km}$ away to the east. The entrance to the cave is $\approx 30$ $\mathrm{m}$ above the Qingjiang River on a steep, vegetated hillside (Fig 2). The hillside continues to an altitude of $900 \mathrm{~m}$ (i.e. $600 \mathrm{~m}$ above the cave entrance) where cave recharge occurs. This recharge zone is hard to access, although one successful expedition in August 2004 noted a thin soil cover of $30 \mathrm{~cm}$ with reasonably dense vegetation.

The climate of this region of China is truly monsoonal, with mean winds reversing seasonally from southerly during the boreal summer, to northerly during the boreal winter. Summer winds are driven by heating of the Asian continent to generate rising air over the continent and a consequent displacement of the Inter-Tropical Convergence Zone into the Northern hemisphere. Inflowing air from the south carries moisture from the Indian Ocean and South China Sea. As this air in turn rises it cools, releasing monsoonal rain (and latent heat to propagate the monsoon warming). These processes lead to high regional rainfall in the summer months. The strength of monsoon rainfall varies from year by year about an average annual value of 1144 $\mathrm{mm} \mathrm{yr}^{-1}\left(+/-240 \mathrm{~mm} / \mathrm{yr}^{-1}\right.$ s.d., based on the last 50 years of data from YiChang) with particularly rainy years (e.g. 1998) leading to significant flooding around the Yangtze River and its tributaries (Ding et al., 2006; Liu and Ding, 2002; Tan, 1999).

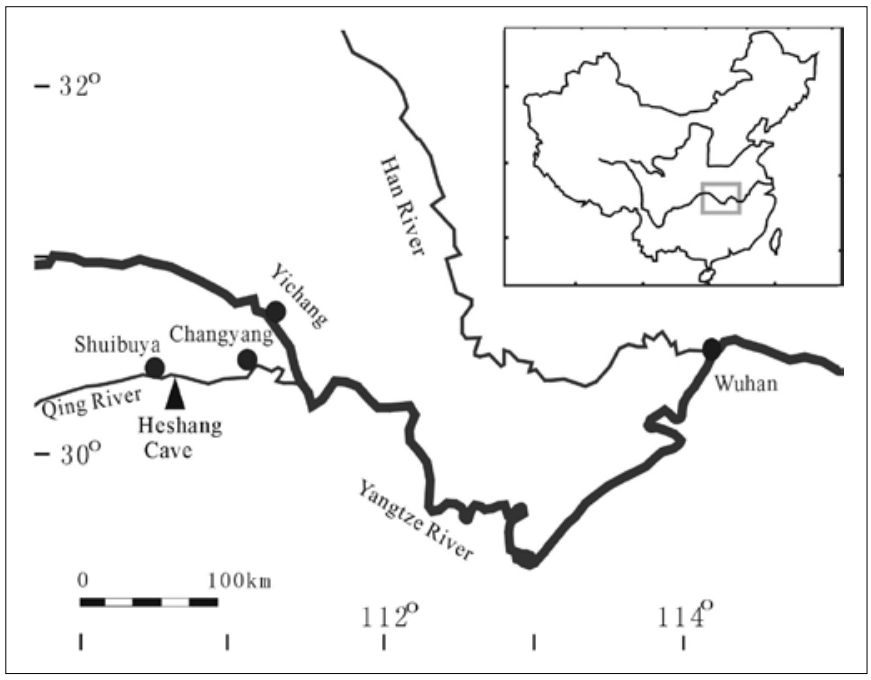

Fig. 1. Schematic map showing the location of Heshang Cave and the main surface drainage. Black dots represent sites of temperature and rainfall stations mentioned in the text.

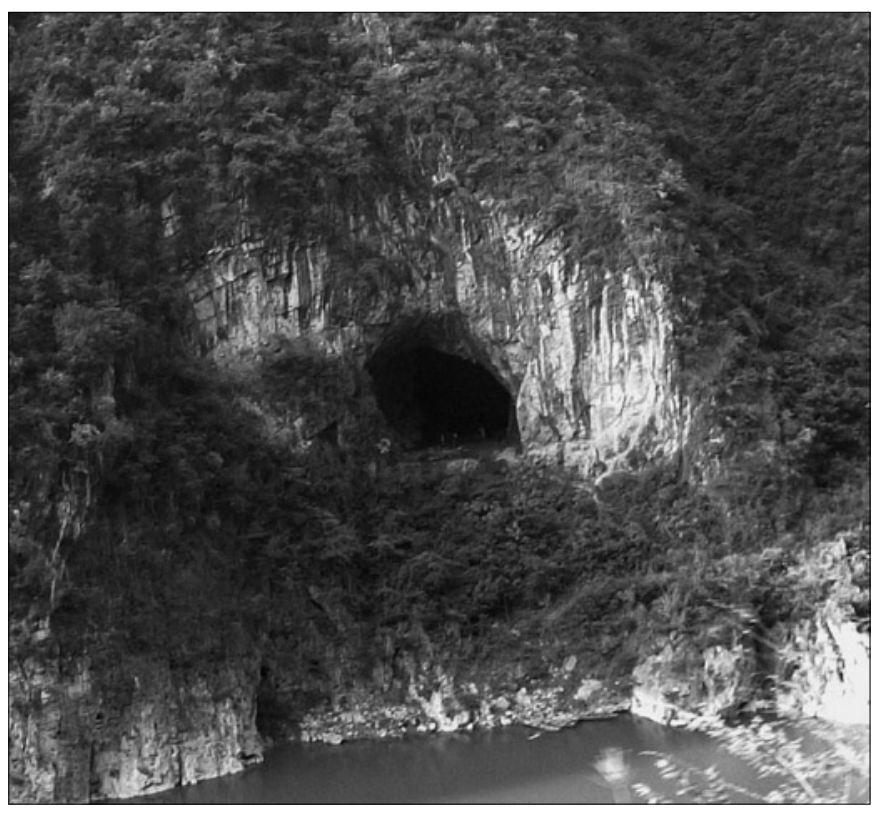

Fig. 2. View of the entrance of Heshang cave from the road on the opposite side of the Qing River. People are just visible in the entrance of the cave, which is $\approx 30 \mathrm{~m}$ above the river (September 2004).

Heshang Cave is a dissolutional cave system formed in Cambrian dolomite. The cave is situated in the hinge zone of the Changyang anticline (Fig. 3), formed in the Cambrian Shangfengjian $(€ 2)$ and Sanyoudong $(€ 3)$ formations. The bedding is typically oriented with a strike of $280^{\circ}$ and dips of $70-80^{\circ}$ in the eastern limb and $25-35^{\circ}$ in the western limb (Wan et al., 1997). Outcrop is common in the region with thicknesses ranging from $600-900 \mathrm{~m}$ for $€ 3$. The orientation of Heshang cave $\left(354^{\circ}\right)$ is consistent with development along local fault and fracture planes, which consist of two groups with dominant strike directions of $10-45^{\circ}$ and $330-350^{\circ}$.

\section{DESCRIPTION OF CAVE}

Heshang has a large, approximately circular, entrance with a height of about $20 \mathrm{~m}$ (Fig 2). The cave is close to horizontal and extends for a distance 


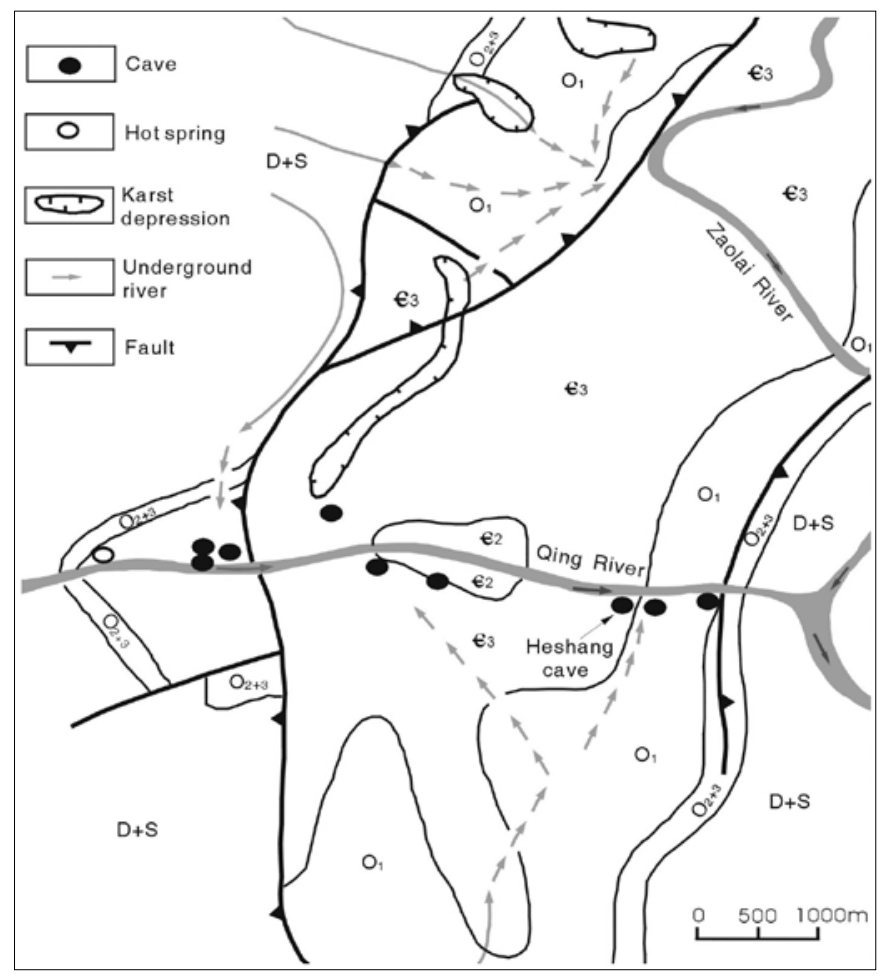

Fig. 3. Hydrology of the region surrounding Heshang Cave (after Wan et al., 1997). Flowing water is marked in grey, with subsurface flow as dashed arrows. Geological features are also shown, marked in black, with fine lines representing boundaries between geological formations, and thick lines faults. Letter identify periods $(€=$ Cambrian; $\mathrm{O}=$ Ordovician; $\mathrm{D}+\mathrm{S}=$ Devonian and Silurian)

of $\approx 250 \mathrm{~m}$ into the hillside without any large changes in height or width (Fig 4). At $250 \mathrm{~m}$, cave breakdown prevents further passage, although it is possible the cave extends beyond this point.

The fairly simple, quasi horizontal nature of this cave suggests that it was likely formed along the local meteoric water-table. This type of cave is very common in the highly fractured carbonate rocks of southern China. Ford and Williams (2007) suggest that water-table caves develop where fissure frequency is high because direct routes between multiple input tubes can be established and the resulting passages can be easily enlarged to absorb all of the flow. Tectonic research suggests that the region underwent 3 periods of uplift, which led to the development of two terraces (Wan et al., 1997; Wang et al., 1999) - an older one at 1100-1200 m and younger one at $490-570 \mathrm{~m}$. These two terraces are vaguely present in the Heshang area. The first is represented by the tops of the hills in which the cave is located and the second is located approximately midway to the top. It is believed that the river began flowing through this region in the middle Pleistocene (Wan et al., 1997). If this is true, then it implies uplift rates of $\approx 1 \mathrm{~m} / \mathrm{kyr}$ so that Heshang cave must be quite young. Its entrance is only $30 \mathrm{~m}$ above the river level suggesting an age of only about $30 \mathrm{kyr}$.

The caveis reasonablywelldecorated with stalagmites, stalactites, flowstones, draperies, rimstone pools, and concretions. There are about 50 stalagmites taller than $30 \mathrm{~cm}$ (Fig 5), approximately 20 percent of which appear to be forming at present from active drips, as

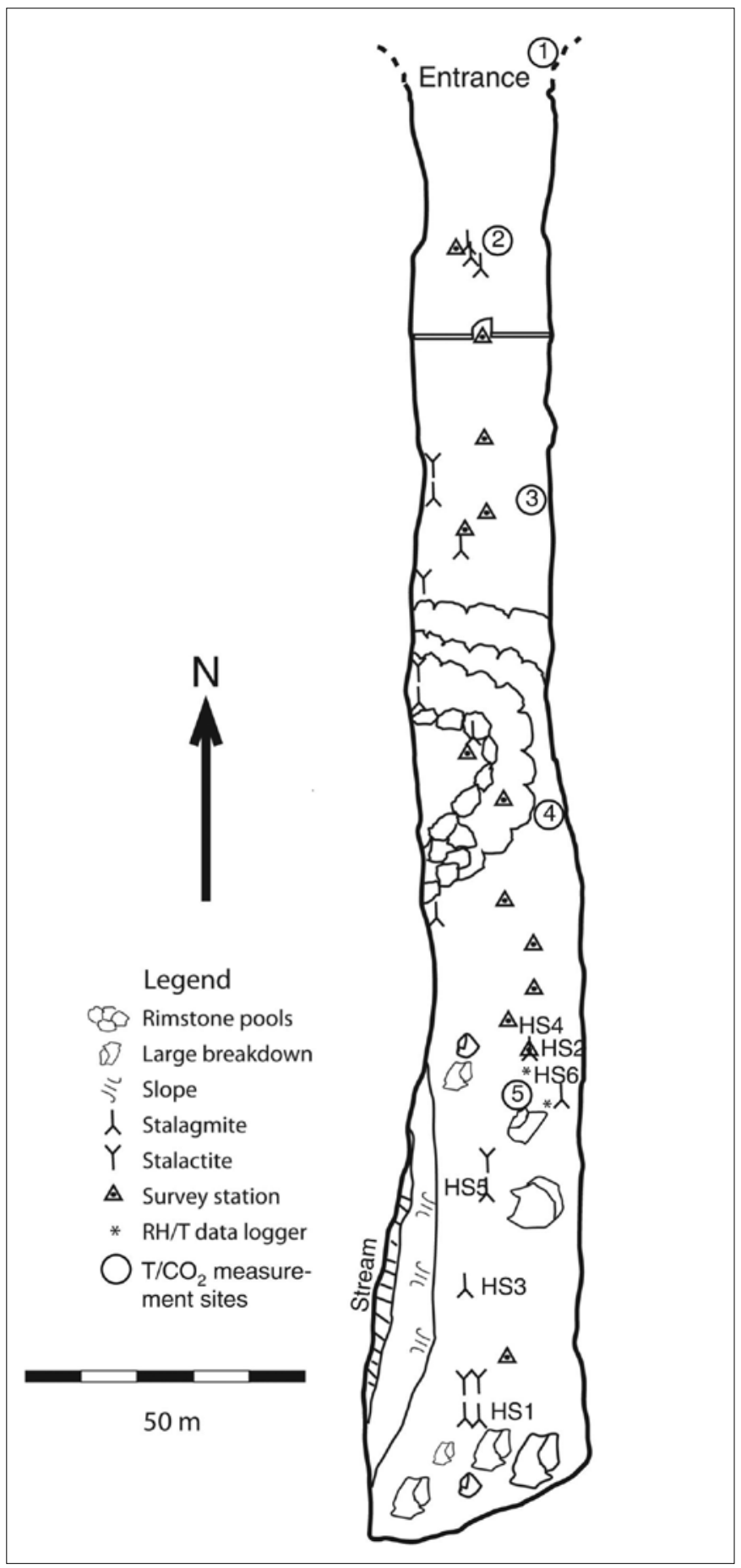

Fig. 4. Schematic plan view map of the interior of Heshang Cave showing the approximate locations of the stalagmites HS1 - HS6, the 2 temperature data loggers (Fig 7), and, the 5 temperature and $\mathrm{pCO}_{2}$ monitoring sites (see Fig. 8).

well as numerous smaller stalagmites. Six of the large stalagmites were removed from Heshang cave between 2001 and 2004 (Fig 5, Table 1). At a distance of 100 $\mathrm{m}$ from the cave entrance are a collection of rimstone pools (Fig 6) covering an area of some $600 \mathrm{~m}^{2}$. Some of these are large with front lips more than $1 \mathrm{~m}$ in height. These are water-filled at present and appear to be actively growing. Decoration on the ceiling is common but unclear to the naked eyes because of the height of the cave ceiling (15-20 m). Close to the sides of the cave quite spectacular stalactite formations can be seen in several locations, normally to the west of 


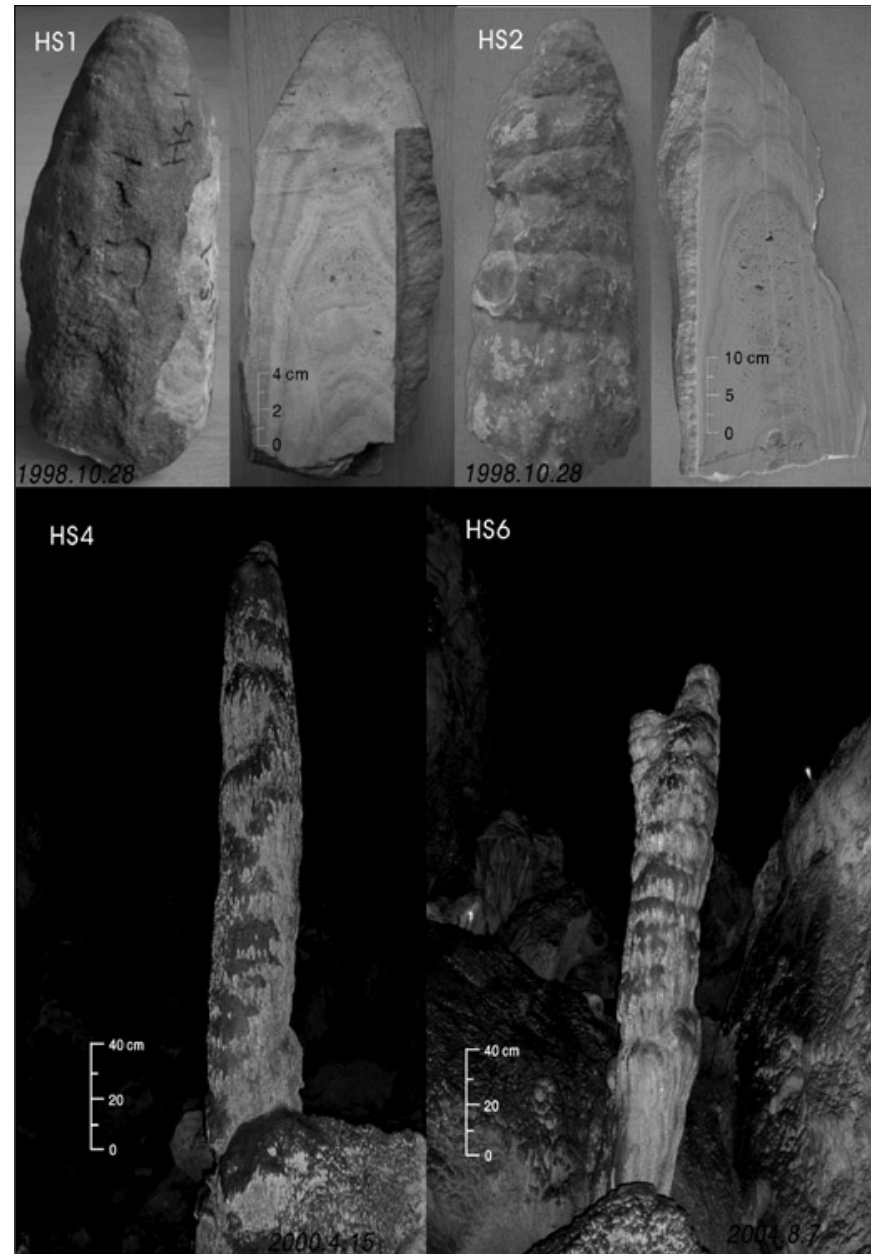

Fig. 5. Photographs of the four significant stalagmite samples recovered from Heshang Cave with scale bars and dates of photographs. For locations of each sample see Fig. 2.

\section{the cave.}

Heshang Cave is wet throughout the year, with active drips, standing pools of water and some flowing water close to the back of the cave. Drip sites can be found from the cave entrance to the deepest point of the cave and have drip rates that vary from 2 to 80 drips per minute, with no obvious pattern of increase or decrease of flow from entrance to back. There are many standing pools of water, with those in the rimstone pools being the most impressive. Many of these pools are the sites of carbonate deposition, with their bottoms often featuring precipitated carbonate nodules. At the back of the cave, on the western side, there is some flow of water in a small stream but this water flows into the floor of the cave before reaching the cave entrance.
There is only limited fauna in the cave. Several bats were seen when the first scientific investigation was carried out in 1997 but bat sightings in recent years have been quite infrequent. People seldom visit the cave because it is only accessible by boat. Some local villagers, however, occasionally reside near the cave entrance in summer. For example, from 1997 the front of the cave was inhabited by a fisherman who seasonally fished in the river below, but he has not been in residence since 2004. A $4 \mathrm{~m}$ high stone wall situated about $40 \mathrm{~m}$ inside the cave with a single entrance was built by local villagers in 2000, when a plan was made to develop Heshang Cave as a show cave. The plan was aborted, however, due to the inconvenient access and small number of potential visitors.

\section{INTERIOR AND EXTERIOR TEMPERATURE}

Temperatures immediately outside Heshang cave have a seasonal range from $3^{\circ} \mathrm{C}$ to $30^{\circ} \mathrm{C}$ and an annual mean of $18^{\circ} \mathrm{C}$. These have been logged since September 2004 using a HOBO H8 PRO T logger recording data every 2 hours. The logger was washed away by flooding on July 10, 2005, when heavy rain fell locally, causing loss of data from April to August 2005 when it was replaced. Since then the replacement logger has been in continuous operation. The logger $\mathrm{T}$ record is in very close agreement with that of the nearest government meteorological station at Changyang (see Fig 1 for location) at both seasonal and shorter timescales (Fig 7).

Temperature inside the cave has been logged at 2 hours resolution since September 20, 2003 using two HOBO H8 PRO T loggers stuck to the rock surface at sites close to the site of the HS-4 stalagmite (two loggers are used to provide redundancy in case of logger failure). Since April 26, 2005, T measurements have also been made at ten-day intervals using a hand-held thermometer incorporated in a Telaire $7001 \mathrm{CO}_{2}$ and $\mathrm{T}$ monitor (Fig 7). Annual averages from both measurement techniques agree and are $18^{\circ} \mathrm{C}$, identical to that outside the cave as expected for shallow cave systems. Systematic differences between the logger and hand-held thermometer are observed, however, in their recording of the seasonal cycle. The loggers indicate a seasonal amplitude of change $\approx 3^{\circ} \mathrm{C}$ smaller and slightly lagged relative to the handheld thermometer. These differences are unlikely to represent thermal memory of the handheld thermometer itself because the device was kept in the

\begin{tabular}{|c|c|c|c|c|c|}
\hline $\begin{array}{c}\text { Sample } \\
\text { name }\end{array}$ & $\begin{array}{c}\text { Height } \\
\text { (cm) }\end{array}$ & $\begin{array}{c}\text { Diameter } \\
\mathbf{( c m )}\end{array}$ & $\begin{array}{c}\text { Date } \\
\text { removed }\end{array}$ & $\begin{array}{c}\text { Age } \\
\text { (ka) }\end{array}$ & Publications \\
\hline HS1 & 28 & 10 & $23 / 10 / 98$ & $3.5-4.2$ & (Hu et al., 2005) \\
\hline HS2 & 62 & 25 & $23 / 10 / 98$ & $10.8-20.1$ & Unknown \\
\hline HS3 & 52 & 20 & $15 / 4 / 01$ & $0-9.2$ & (Hu et al., 2000; Johnson et al., 2006) \\
\hline HS4 & 254 & 40 & $15 / 4 / 01$ & Unknown & \\
\hline HS5 & 32 & 20 & $15 / 4 / 01$ & $0-4.9$ & \\
\hline HS6 & 208 & 40 & $7 / 8 / 04$ & &
\end{tabular}

Tab. 1. Summary of stalagmite samples recovered from Heshang Cave 


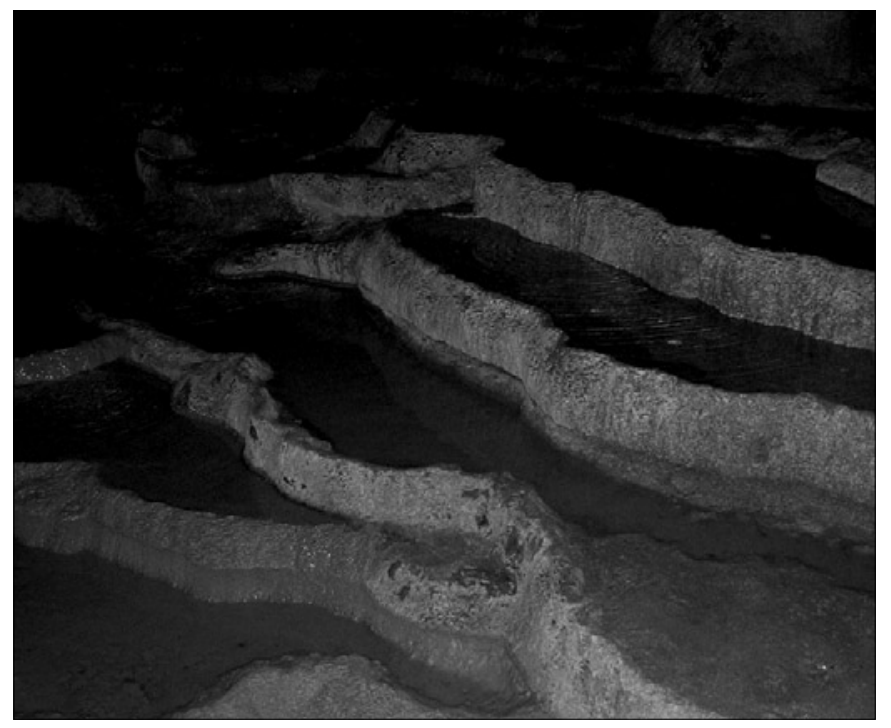

Fig. 6. Example of rimstone pool formation in Heshang Cave (close to $\mathrm{CO}_{2} / \mathrm{T}$ station 4 on Fig. 4). Front walls of the pools in this image are $\approx 20-30 \mathrm{~cm}$ in height. Note that the pools are full, leading to a moist atmosphere in the cave (September 2004).

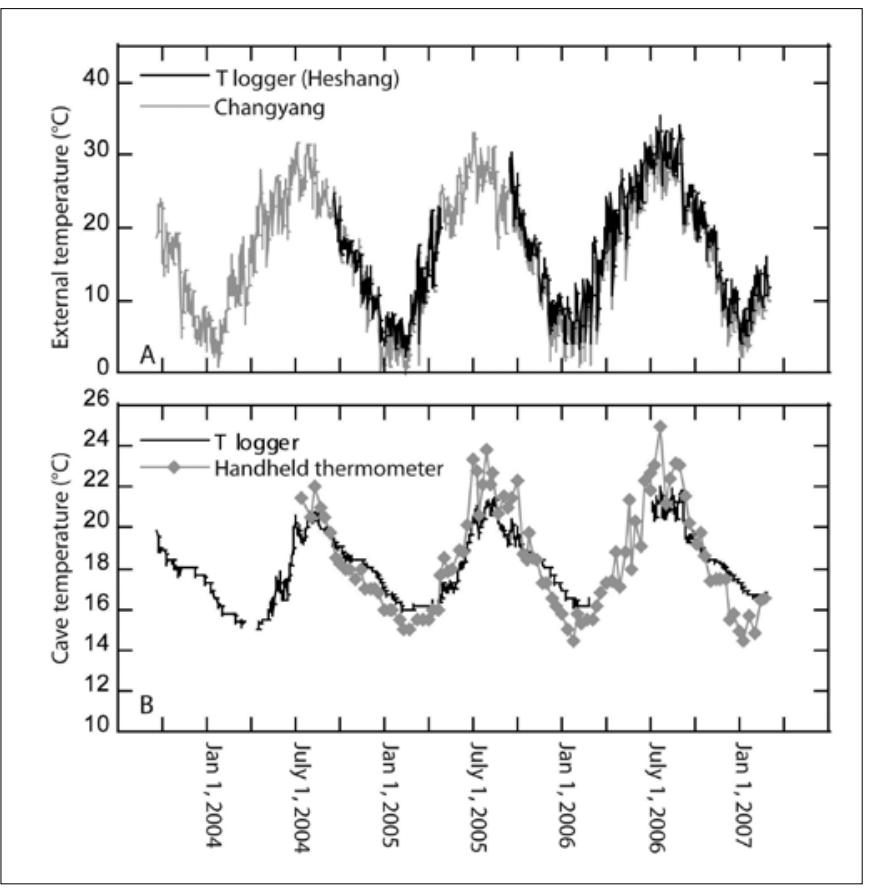

Fig. 7. Thirty month record of: (A) external temperature variations at Heshang Cave recorded by a Hobo T logger placed directly outside the cave entrance and by a nearby meteorological station in Changyang $\left(30^{\circ} 28^{\prime} \mathrm{N}, 111^{\circ} 11^{\prime} \mathrm{E}, 144.2 \mathrm{~m}\right)$, and $(\mathrm{B})$ average cave temperature variations recorded by 2 HOBO $\mathrm{H} 8 \mathrm{PRO}$ T loggers placed inside the cave (Fig. 4 for locations) and cave temperatures measured with a handheld thermometer $\left(\mathrm{pCO}_{2}\right.$ monitor) every 10 days.

cave for more than 30 minutes before recording $\mathrm{T}$. It seems more likely that the difference reflects small offsets between the $\mathrm{T}$ of air in the cave, and the $\mathrm{T}$ of the rock surface to which the loggers are stuck. The heat capacity of the rock may impart a thermal lag on $\mathrm{T}$ and dampen the total range of $\mathrm{T}$ observed.

For consideration of speleothem growth conditions, the logger data is likely to be more appropriate, because it reflects $T$ of the rock surface on which new growth occurs. This logger data shows a seasonal range from $16^{\circ} \mathrm{C}$ to $21^{\circ} \mathrm{C}$ and is therefore damped by a factor of five relative to the exterior seasonal range. The internal $\mathrm{T}$ cycle is also lagged behind the external cycle by about 10 days. The presence of this damped cycle in Heshang is a consequence of the shallow nature of the cave and the large opening, allowing ready circulation of air into the cave. To further investigate this seasonal cycle, during the third year of monitoring (April 2006 - May 2007) temperature was also measured every ten days at five points within the cave stretching from the cave entrance (Point 1) to the site of the HS4 Stalagmite (Point 5). This data clearly indicates the penetration and damping of the seasonal cycle in the cave (Fig 8).

\section{RAINFALL AND DRIPWATERS}

Rainfall data from stations close to Heshang Cave show a summer maximum, reflecting precipitation of the East Asian Monsoon system. Government meteorological stations at Changyang and Yichang are supplemented by a rainfall monitoring station (established as part of the planning for a local dam) at Shuibuya, only $3 \mathrm{~km}$ from Heshang (Fig 1). Daily data from these three stations is shown in Fig 9, together with monthly averages (calculated as the average of the preceding 30 days). Summer daily rainfall occasionally reached values greater than $90 \mathrm{~mm} /$ day, with the highest daily rainfall recorded during 2003 2007 being $120 \mathrm{~mm}$ in a single day. Monthly averages fall to close to zero rainfall in the dry season (JanuaryFebruary) and peak at between $7 \mathrm{~mm}$ /day and 14 $\mathrm{mm} /$ day in the wet season (centred on August).

There is a pronounced difference in the pattern of summer rainfall between the three years of the monitoring period (Fig 9). In 2004, the monsoon onset was abrupt and relatively early, followed by heavy rains for about four months and a reasonably abrupt end to the summer monsoon (giving a total May-Oct rainfall of $844 \mathrm{~mm}$ ). In 2005, monsoon onset was more gradual and rainfall was relatively low until August when heavy rain fell for a period of about two months (total May-Oct rainfall of 781 $\mathrm{mm}$ ). During 2006, by contrast, monsoon rainfall was generally lower (total May-Oct rainfall of $571 \mathrm{~mm}$ ) with few extremely wet days, and monthly averages below $8 \mathrm{~mm} /$ day throughout the season at all three monitoring stations.

Drip rates within Heshang Cave have been measured at 10-day intervals for three years from March 2004 to February 2007. Measurements are made at the site of recovery of the HS-4 stalagmite for a duration of 2 minutes. Every fourth measurement (i.e. every 40 days) was made by scientists from the China University of Geosciences (Wuhan) during their regular visits to the cave site. Other measurements are made by a local resident (Shouwu Qing) who is contracted to make a set of measurements and collections at ten-day intervals. In addition to these drip-rate measurements, he measures the 10-day $\mathrm{T}$ record (Fig 7) and collects drip-water samples for chemical analysis.

Dripping is continuous throughout the year with 


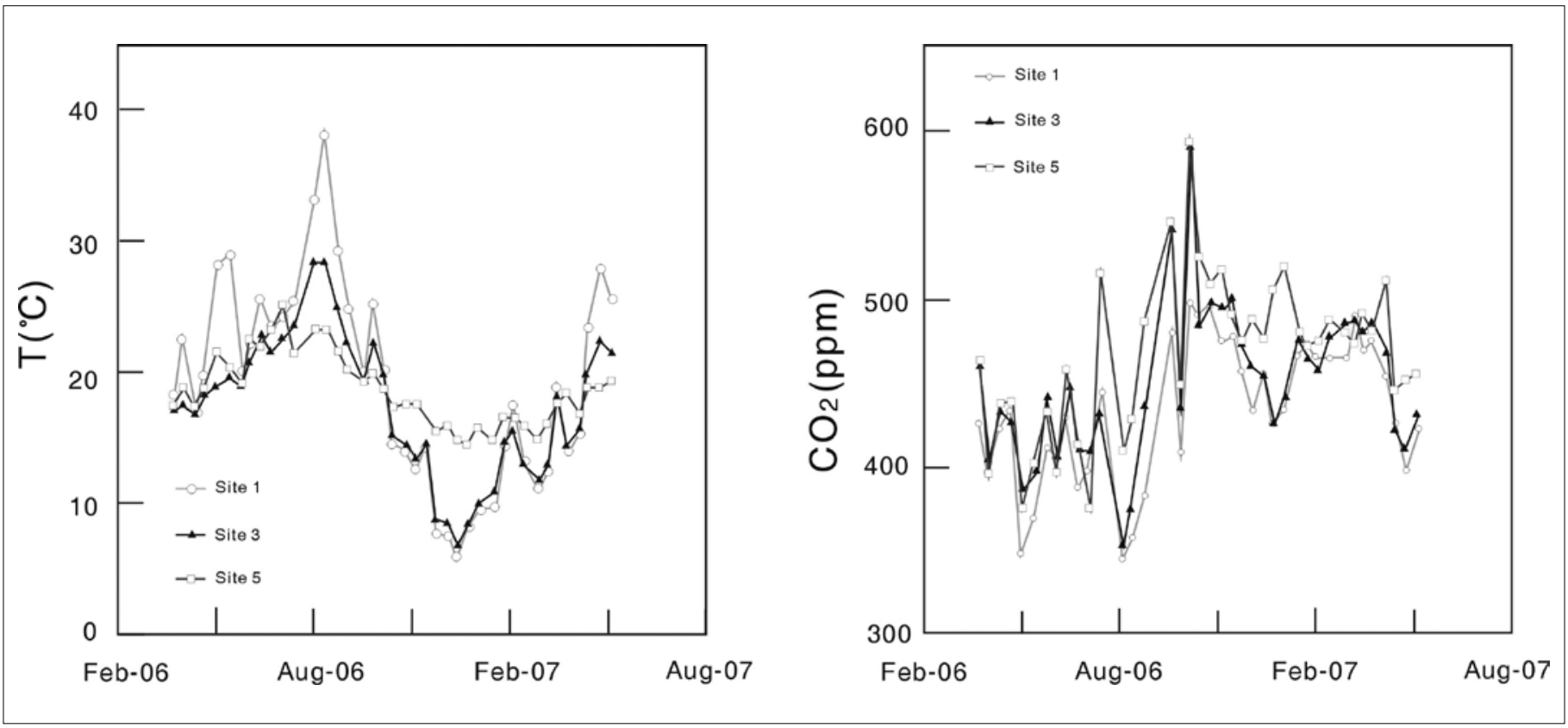

Fig. 8. Temperature and $\mathrm{CO}_{2}$ measured at three points within Heshang Cave, from the entrance to the site of HS-4 (see Fig. 4 for location of measurements - data shown here represent Sites 1, 3 and 5).

a baseline value of $\approx 14$ drips/minute (Fig 10). This corresponds to a flow-rate of $\approx 2 \mathrm{ml} / \mathrm{min}$, assuming a drip volume of $\approx 0.14 \mathrm{ml}$ (Genty \& Deflandre, 1998). Two pronounced peaks in drip rate are observed, up to values of $\approx 40$ drips/minute, corresponding to the summer monsoons of 2004 and 2005. No such peak is observed in 2006, reflecting the lower summer rainfall that year. Increases in drip rate are very sharp and presumably reflect a change in hydrological regime within the overlying karst system as the summer monsoon rain saturates the system. This increase is observed in June for both 2004 and 2005, and its absence in 2006 reflects lower rainfall in the immediately preceding months. The threshold behaviour exhibited in the system has important implications for the use of geochemical measurements on stalagmites for the reconstruction of past climate. The system is likely to be particularly strongly influenced by the intensity of rainfall in a short period, particularly during the early months of the summer monsoon. This flow-responsiveness to rainfall levels for the HS-4 drip places it in the "intermediate" category of Baldini et al. (2006), a category expected to be particularly appropriate for growth of speleothems capturing seasonal climate information. Decreases in drip-rate as the summer monsoon ends are more gradual and rates tail off towards the baseline value over the remainder of the year until the next monsoon onset. This flow regime is similar to that observed in a monitoring study at Pere Noel Cave (Belgium, Genty \& Deflandre, 1998), with an abrupt increase in drip-rate soon after the start of seasonal rainfall (in the winter in that case) and a more gradual decrease. Further work on Heshang could assess the hydrological regime that leads to such threshold behaviour (e.g. Fairchild et al., 2006) to aid interpretation of palaeoclimate records.

To assess changes in drip rate at a higher resolution we have also installed a Stalagmate automatic acoustic drip-rate counter (http://www.driptych.com/). The hope is that such instruments will negate the need for regular human observation of the drip rate, and can provide data at sufficiently high resolution that the response of karst hydrology to individual rainfall events can be observed. A Stalagmate device was installed on May 23, 2006 under the drip that formed stalagmite HS-4. It was placed in a large funnel immediately under the drip and, separated by a thin plastic strip as a spacer, was covered by a glass plate onto which the drip fell. This arrangement allowed for synchronous growth of glass-plate calcite, counting of drips, and collection of water in a bucket beneath the funnel. Drips were counted at ten minute resolution for ten months, with data downloaded four times during this period. The ten minute data is rather noisy, with variations in measured drip rate between adjacent measurements that do not appear to be real based on direct observations. The reasons for this noise are not clear, although some of it undoubtedly reflects the drip missing the Stalagmate device for short periods. These periods of missing counts can readily be removed from the data, resulting in about $6 \%$ data rejection. Daily averaging of remaining data indicate that the average Stalagmate count rate is close to the direct observations (Fig 11). The Stalagmate data shows considerable variation day to day and generally more structure than the directly observed drip rate data. It is not yet clear how much of this Stalagmate variation is real and further testing of the device against direct observations is required. There is, however, no apparent relationship between this short-term variation and rainfall at any of the three monitoring stations shown in Fig 9. A broader increase in Stalagmate counts in August and September 2006 corresponds to the higher rainfall of the summer monsoon and suggests some hydrological response to this rainfall even in this relative dry year. It is noteworthy, though, that the Stalagmate data support 

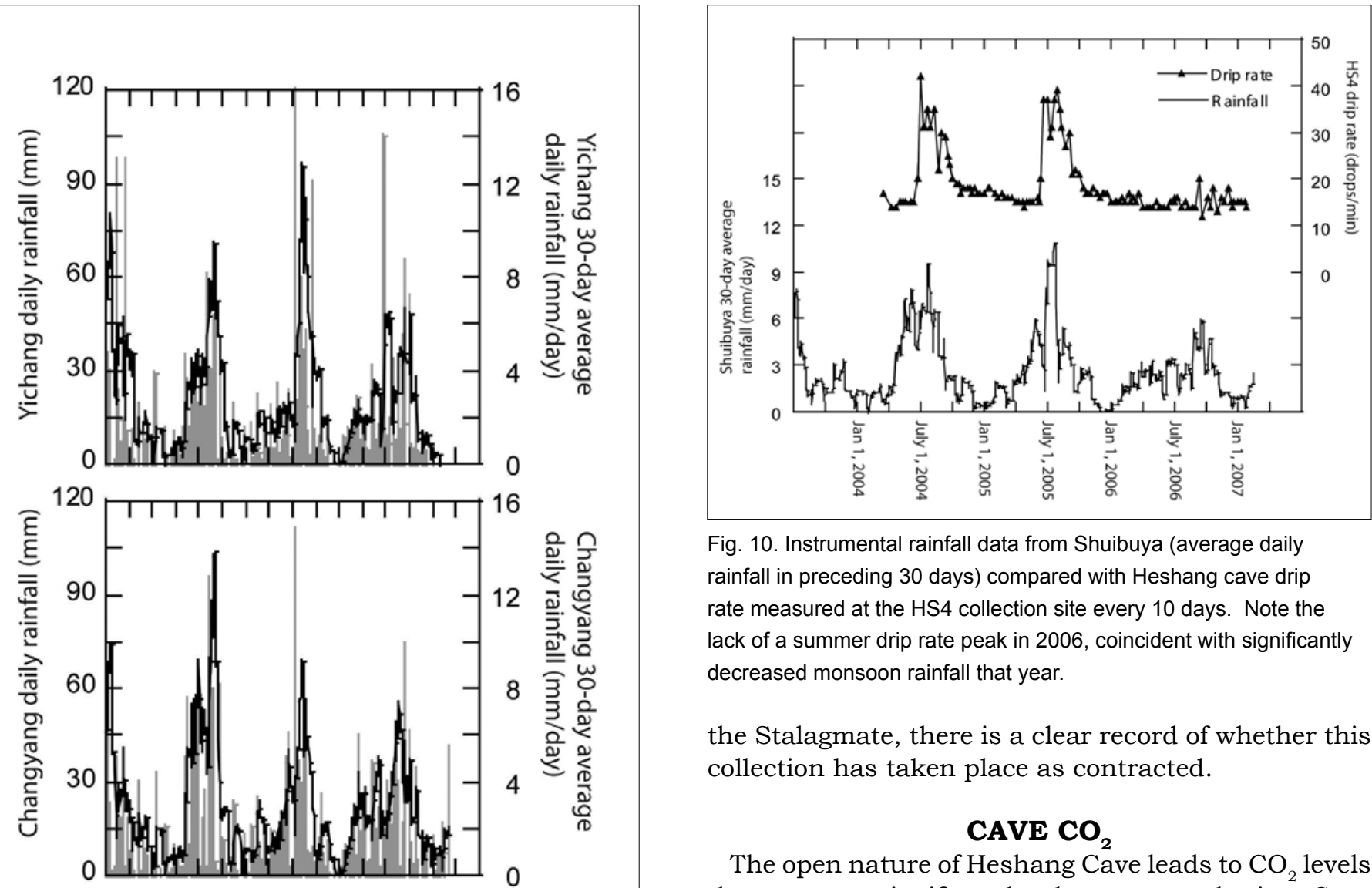

Fig. 10. Instrumental rainfall data from Shuibuya (average daily rainfall in preceding 30 days) compared with Heshang cave drip rate measured at the HS4 collection site every 10 days. Note the lack of a summer drip rate peak in 2006 , coincident with significantly decreased monsoon rainfall that year.

the Stalagmate, there is a clear record of whether this collection has taken place as contracted.

\section{CAVE $\mathrm{CO}_{2}$}

The open nature of Heshang Cave leads to $\mathrm{CO}_{2}$ levels that are not significantly above atmospheric. Cave $\mathrm{CO}_{2}$ has been measured at 10-day intervals between April 2006 and March 2007 at five points in the cave ranging from the entrance to the site of the HS-4 stalagmite (see Fig 4 for locations) using a Telaire $7001 \mathrm{CO}_{2}$ and $\mathrm{T}$ monitor (with a quoted precision of $\pm 20 \mathrm{ppmV}$ and accuracy of $\pm 50 \mathrm{ppmV}$ ). Values range from 335 to $592 \mathrm{ppmV}$ with higher values in the second half of the measurement period. There is presently too little data to indicate the presence/ absence of an annual cycle in $\mathrm{CO}_{2}$. Average values for the measurement period increase systematically from the cave entrance (430 ppmV) to the site of HS-4 (465 ppmV) (Fig 12) due to the degassing of $\mathrm{CO}_{2}$ from infiltrating karst waters (and/or from gas-filled pockets within the karst itself (Ek \& Gewelt, 1985)). These levels of $\mathrm{CO}_{2}$ are not high enough, even in the cave interior, to make a significant difference to the degassing rate of $\mathrm{CO}_{2}$ from drip-waters so cave $\mathrm{CO}_{2}$ levels are not expected to exert control on speleothem growth rate or chemistry.

\section{ONGOING MONITORING AND PALAEOCLIMATE WORK} monsoon seasonality in the rainfall data, with the majority of rainfall occurring between May and September each year, and that summer rainfall is about $30 \%$ lower in 2006 than in the preceding two years.

the direct observations of drip rate in indicating that drip-rates never reached the high value (up to 40 drips per minute) observed in 2004 and 2005. An additional positive aspect of deploying a Stalagmate is that it provides a check on the collection of drip water samples by the local resident. He collects drip-waters above the Stalagmate every ten days at a recorded

time. Since the collection stops the drips from striking

Fig. 9. Instrumental rainfall data from 3 stations near Heshang Cave: Shuibuya, Changyang, and Yichang. Daily values are shown in grey (left axis) while the 30-day mean (average daily rainfall in the preceding 30 days) is shown in black (right axis). Note the strong 


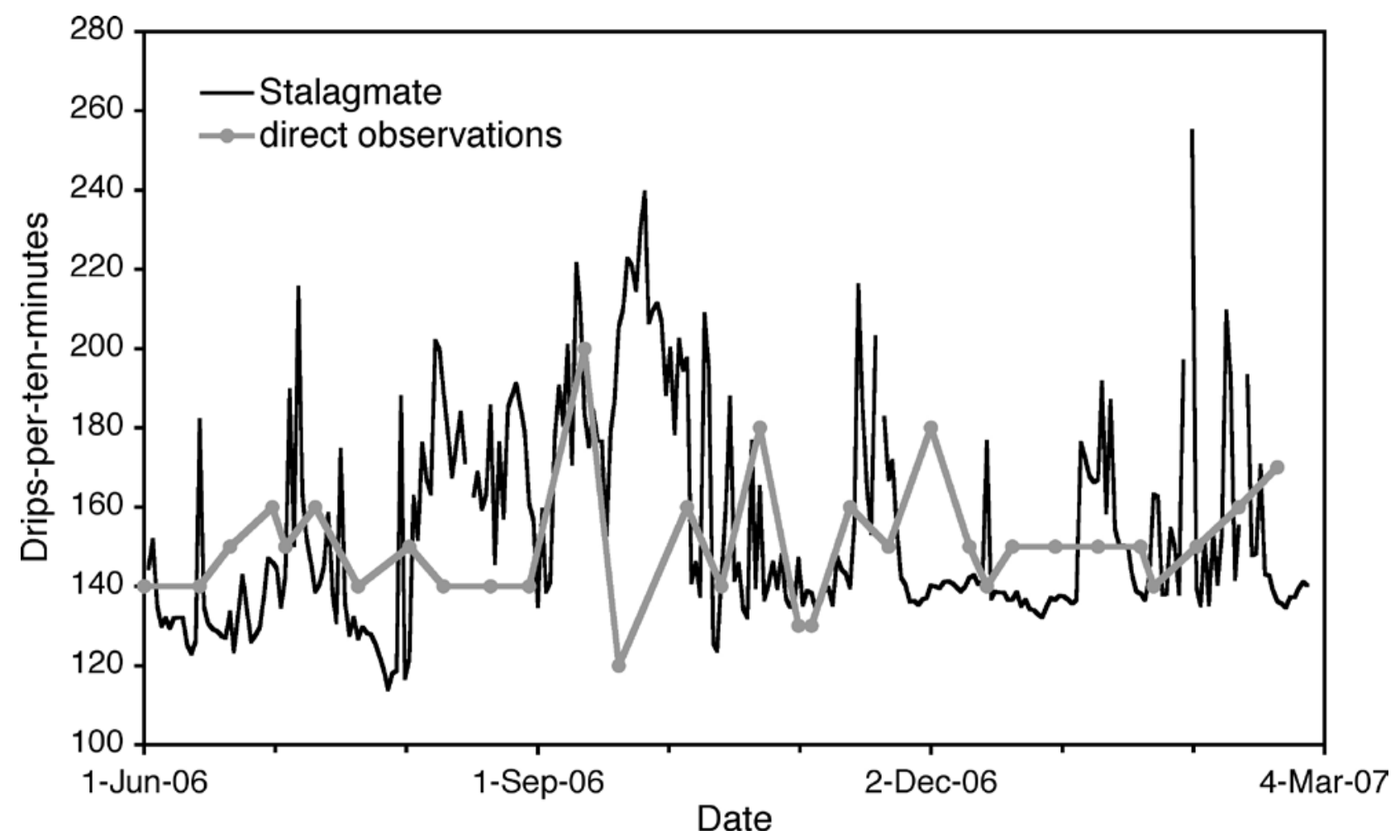

Fig. 11. Nine months of continuous drip-rate data from a Stalagmate automatic drip counter, compared with direct observations at 10-day intervals (Fig. 10). Stalagmate data was collected every ten minutes, and averaged per day. The Stalagmate appears to record the daily average reasonably well, although the reliability of short-term structure in measured drip-rate is not clear. Note, though, that the relatively high values observed in August and September 2006 correlate well with a period of late monsoon rainfall in the region (see Fig. 10).

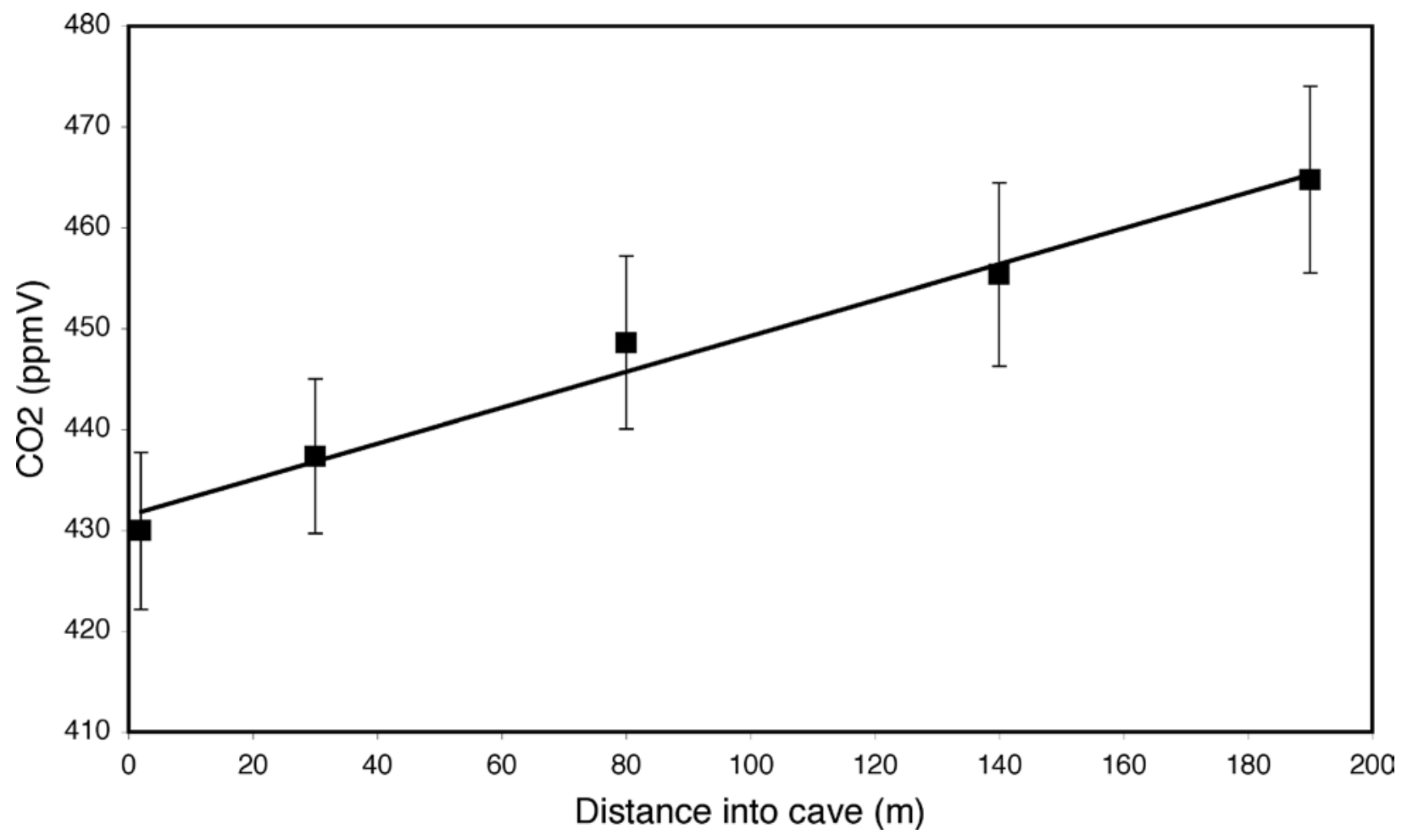

Fig. 12. Average $\mathrm{CO}_{2}$ levels (April 2006-March 2007) plotted against distance into the cave showing a linear increase of $0.23 \mathrm{ppmV} \mathrm{m-1.} \mathrm{Errors} \mathrm{are}$ standards errors based on 31 measurements 
with a range of geochemical measurements on dripwaters, speleothems, and carbonates grown on glass plates placed under two of the active drips in Heshang. Results and interpretation of trace element and stable isotope data on these glass plates will be presented in forthcoming papers and will aid in interpreting developing records for the 20th century and for earlier periods, particularly from stalagmite HS-4.

More generally, it is clear that thorough monitoring work is required if the environmental and geochemical response of cave systems is to be interpreted in terms of climate change. Only by such monitoring work will the community be able to fully understand the range of possible geochemical proxies captured in speleothems and unlock this rich archive of palaeoclimate.

\section{ACKNOWLEDGEMENTS}

This work was funded by NSFC grants 40531004 and 40472150, and UK-NERC grant NE/B503925/ 1. We thank Mr Shouwu Qing for collection of 10-day drip-water samples and temperature data. Mr Zhifang Xiong, Mr. Zhongwu Ma, Mr. Zhenhua Cao and Miss Luyao He are also thanked for help with field work at Heshang on frequent occasions.

\section{REFERENCES}

Baldini J. U. L., McDermott F. \& Fairchild I. J., 2006 Spatial variability in cave drip water hydrochemistry: Implications for stalagmite paleoclimate records. Chemical Geology, 235: 390-404.

Ding Y.-H., Shi X.-L., Liu Y.-M., Liu Y., Li Q.-Q., Qian Y.-F., Miao M.-Q., Zhai G.-Q. \& Gao K., 2006 - Multiyear Simulations and Experimental Seasonal Predictions for Rainy Seasons in China by Using a Nested Regional Climate Model (RegCM NCC). Part I: Sensitivity Study. Advances in Atmospheric Sciences, 23: 323-341.

Ek C. \& Gewelt M., 1985 - Carbon-dioxide in cave atmospheres - new results in Belgium and comparison with some other countries. Earth Surface Processes and Landforms, 10: 173-187.

Fairchild I. J., Baker A., Borsato A., Frisia S., Hinton R. W., McDermott F. \& Tooth A. F., 2001 - Annual to sub-annual resolution of multiple trace-element trends in speleothems. Journal of the Geological Society of London, 158: 831-841.

Fairchild I. J., Tuckwell G. W., Baker A. \& Tooth A. F., 2006 - Modelling of dripwater hydrology and hydrogeochemistry in a weakly karstified aquifer (Bath, UK): Implications for climate change studies. Journal of Hydrology, 321: 213-231.

Ford D. \& Williams P., 2007 - Karst Hydrogeology and Geomorphology. Chichester, Wiley: 561 p.

Genty D. \& Deflandre G., 1998 - Drip flow variations under a stalactite of the Pere Noel cave (Belgium). Evidence of seasonal variations and air pressure constraints. Journal of Hydrology, 211: 208-232.
Hu C., Henderson G. M., Huang J., Xie S., Sun Y. \& Johnson K. R., 2008 - Quantification of Holocene Asian monsoon rainfall from spatially separated cave records. Earth \& Planetary Science Letters, 266(3-4): 221-232.

Hu C., Huang J., Fang N., Xie S., Henderson G. M. \& Cai Y., 2005 - Dissolved Si in stalagmite carbonate as a proxy for past rainfall. Geochimica and Cosmochimica Acta, 69: 2285-2292.

Johnson K. R., Hu C. Y., Belshaw N. S. \& Henderson G. M., 2006 - Seasonal trace element and stable isotope variations in a Chinese speleothem: The potential for high-resolution paleomonsoon reconstruction. Earth \& Planetary Science Letters, 244: 394-407.

Krishna Kumar K., Rajagopalan B. \& Cane M. A., 1999 - On the weakening relationship between the Indian Monsoon and ENSO. Nature, 284: 2156-2159.

Liu Y.-M. \& Ding Y.-H., 2002 - Simulation of heavy rainfall in the summer of 1998 over China with regional climate model. Acta Meteorologica Sinica, 166: 346-362.

McDonald J., Drysdale R. \& Hill D., 2004 - The 20022003 El Nino recorded in Australian cave drip waters: Implications for reconstructing rainfall histories using stalagmites. Geophysical Research Letters: 31: L22202, doi:10.1029/2004GL020859.

Tan S.-K., 1999 - Deep thoughts of land utilization about the rarely severe flooding disaster along the middle and lower reaches of the Changjiang River in 1998. Chinese Geographical Science, 9: 1-11. DOI:10.1007/s11769999-0014-3.

Treble P., Shelley J. M. G. \& Chappell J., 2003 - Comparison of high resolution sub-annual records of trace elements in a modern (1911-1992) speleothem with instrumental climate data from southwest Australia. Earth \& Planetary Science Letters, 216: 141-153.

Wan J.-W., Shen J.-F. \& Chao N.-Y., 1997 - The characteristics of Karst cave development and tourism resources in Banxia area of the Qingjiang River. Carsologica Sinica, 16: 268-278 (in Chinese).

Wang Y. J., Cheng H., Edwards R. L., He Y. Q., Kong X. G., An Z. S., Wu J. Y., Kelly M. J., Dykoski C. A. \& Li X. D., 2005 - The Holocene Asian monsoon: Links to solar changes and North Atlantic climate. Science, 308: 854857.

Wang Y. L., Cheng H., Edwards R. L., An Z. S., Wu J. Y., Shen C.-C. \& Dorale J. A., 2001 - A high-resolution absolute-dated late Pleistocene monsoon record from Hulu Cave, China. Science, 294: 2345-2348.

WangZ.-Y., Wan J.-W. \&Yao, C.-H., 1999- The development of characteristics of Karst caves in Qingjiang river basin. Carsologica Sinica, 18: 151-158 (in Chinese).

Webster P. J., Magana V. O., Palmer T. N., Shukla J., Tomas R. A., Yanai M. \& Yasunari T., 1998 - Monsoons: Processes, predictability, and the prospects for prediction. Journal of Geophysical Research-Oceans 103, 1445114510 . 